\title{
Herpes Viruses, Alzheimer's Disease, and Related Dementias: Unifying or Confusing Hypothesis?
}

\author{
Avindra Nath ${ }^{1}$ \\ Published online: 14 January 2019 \\ (C) This is a U.S. government work and its text is not subject to copyright protection in the United States; however, its text may be subject to foreign copyright \\ protection 2019
}

Since the original publication by Tzeng et al. [1] showing in a retrospective study that patients who received antiherpetic therapy for mucosal or skin eruption by Herpes simplex viruses type 1 and 2 (HSV-1, HSV-2) had a lower risk of microvascular dementia, Alzheimer's disease (AD), and "other dementias," there has been wide publicity about the possible association of human herpes viruses 6 and 7 (HHV-6, HHV-7) with $\mathrm{AD}$. This warrants that we discuss these viruses together to see if there might be a unifying hypothesis. It is important to recognize that Herpes viruses are a family of viruses that consists of HSV-1, HSV-2, varicella zoster virus (VZV; HHV-3), Epstein Barr virus (EBV; HHV-4), cytomegalovirus (CMV; HHV-5), HHV-6A, HHV-6B, HHV-7, and HHV-8 that are known human pathogens. Each of these is a distinct virus and causes very distinct clinical syndromes. For example, HSV-1 most often causes herpes labialis, HSV-2 causes genital herpes, VZV is the cause of chicken pox and shingles, EBV causes infectious mononucleosis, HHV-6 causes a skin rash called roseola, some cases of roseola can be caused by HHV-7, and HHV-8 can cause Kaposi's sarcoma in immunosuppressed individuals such as patients with AIDS. Some of the herpes viruses have been associated with acute neurological syndromes. For example, HSV-1 can cause an acute encephalitis, HSV-2 can cause a viral meningitis, while VZV can cause an arteritis leading to a stroke, and CMV and HHV-6 can cause an acute encephalitis in immunocompromised individuals (reviewed in [2]).

However, once the host is infected with any of the herpes viruses, the virus persists in tissue reservoirs for the life of the individual, and reactivation of these viruses is prevented by

Avindra Nath

natha@ninds.nih.gov

1 Section of Infections of the Nervous System, National Institute of Neurological Disorders and Stroke, National Institutes of Health, Bldg 10; Room 7C-103, 10 Center Drive, Bethesda, MD 20892, USA the immune system. Hence, it is plausible that there may be small amounts of periodic reactivation, and this may lead to chronic pathological conditions. In fact, some of the herpes viruses have been associated with a wide variety of chronic diseases, although cause and effect has been harder to prove. Most evidence remains circumstantial, and definitive studies have not been performed. This is particularly true for HHV-6, which has been associated with a wide variety of unrelated neurological and systemic diseases. These include multiple sclerosis, epilepsy, chronic fatigue syndrome, autism, and mood disorders to name a few. See www.hhv-6foundation. org for a comprehensive list. This is further complicated by the fact that nearly $1 \%$ of the population has chromosomally integrated HHV-6, the clinical significance of which remains unclear [3]. And now HHV-6A and HHV-7 have been associated with $\mathrm{AD}[4,5]$, and HSV-1 and 2 have been associated with all types of dementias [1]. It is inconceivable that each of these viruses can cause so many distinct diseases. This is further complicated by the fact that besides these herpes viruses, a large number of other viruses, bacteria, and fungi have been associated with $\mathrm{AD}$ [6-8]. It is also inconceivable that so many diverse pathogens can all cause AD. So, could these associations then be epiphenomena? One possibility might be that these viruses and other pathogens get activated as a result of the immune dysregulation that underlies these diseases. However, the mere detection of these pathogens in disease states does not mean that they have a causative or pathophysiological role in the disease.

Readhead et al. [4] analyzed RNA and DNA sequencing data from a large number of patients with $\mathrm{AD}$ and found that there was increased expression of HHV-6A, HHV-6B, and HHV-7 in different regions of the brain, such that, in some regions, one or the other virus was expressed. The study lacks appropriate disease control brains. However, there was additional gene dysregulation that has been implicated in viral infections including a decrease of miR-155. In the APP/PS1 transgenic mice, knocking out miR-155 caused acceleration of amyloid plaque formation 
including amyloid oligomers. These findings were interpreted to suggest that these herpes viruses may promote amyloidogenesis, and the authors concluded that HHV-6A and HHV-7 play an important role in the development and progression of $\mathrm{AD}$. While this may be an intriguing possibility, perturbation of gene expression levels is not the same as knocking out a gene; hence, the significance of these findings needs to be interpreted with caution. In an accompanying paper, Eimer et al. [5] showed that amyloid beta peptide oligomers bind to the herpesvirus surface glycoproteins, accelerating deposition of amyloid plaques, and protecting the brain by viral entrapment. These were determined in the 5XFAD mouse model of AD and 3D human neural cell cultures infected with HSV-1, HHV-6A, and HHV-6B. It would have been good to know if the same viral networks found in $\mathrm{AD}$ brains were perturbed in these models as well. As such, it seems a bit difficult to reconcile the findings from both papers. The first suggests that the acceleration of amyloidogenesis is indirectly mediated by herpes viruses through regulation of other genes and miRs, and that the dysregulation of viral networks might be detrimental. The second paper suggests that the viruses directly interact with amyloid beta peptides and get sequestered in the plaques and, hence, the phenomenon is protective to the brain. This is further complicated by the observation that a wide variety of substances have been shown to accelerate amyloid plaque formation, many of which have been implicated in AD. We showed that the Tat protein of the human immunodeficiency virus also has a similar effect [9]. Hence, the relative role of these viruses in mediating the pathology of $\mathrm{AD}$ is still unclear. Even if these viruses accelerate the amyloid pathology in the brain, the role of amyloid plaques in mediating $\mathrm{AD}$ itself is controversial. In another recent paper where HHV-6 A or HHV-6B was transmitted to marmosets, it caused multiple sclerosis like pathology by exacerbation of experimental allergic encephalomyelitis and not AD [10].

So then how does the study from Taiwan by Tzeng et al. [1] claiming that antiherpetic therapy for cutaneous herpes can prevent $\mathrm{AD}$ and other forms of dementia including microvascular dementia fit into all of this. Despite the numerous caveats in this study [11], even if one were to take the conclusions of this study at face value, the drugs used to treat HSV-1 and 2 have little or no effect on HHV-6A, HHV-6B, or HHV-7. Hence, the findings of this study by Tzeng et al. [1] do not support those of the other two studies by Readhead et al. [4] and Eimer et al. [5]. In conclusion, it is difficult to come up with a unifying hypothesis based on these studies which have further added to the confusion of the role of herpes viruses in $\mathrm{AD}$.
Required Author Forms Disclosure forms provided by the authors are available with the online version of this article

Publisher's Note Springer Nature remains neutral with regard to jurisdictional claims in published maps and institutional affiliations.

\section{References}

1. Tzeng NS, Chung CH, Lin FH, Chiang CP, Yeh CB, Huang SY, Lu RB, Chang HA, Kao YC, Yeh HW, Chiang WS, Chou YC, Tsao CH, Wu YF, Chien WC. 2018. Anti-herpetic Medications and Reduced Risk of Dementia in Patients with Herpes Simplex Virus Infections-a Nationwide, Population-Based Cohort Study in Taiwan. Neurotherapeutics 15:417-429.

2. Whitley RJ. 1996. Herpesviruses. In th, Baron S (ed), Medical Microbiology, Galveston (TX).

3. Liu S, Huang S, Chen F, Zhao L, Yuan Y, Francis SS, Fang L, Li Z, Lin L, Liu R, Zhang Y, Xu H, Li S, Zhou Y, Davies RW, Liu Q, Walters RG, Lin K, Ju J, Korneliussen T, Yang MA, Fu Q, Wang J, Zhou L, Krogh A, Zhang H, Wang W, Chen Z, Cai Z, Yin Y, Yang H, Mao M, Shendure J, Wang J, Albrechtsen A, Jin X, Nielsen R, Xu X. 2018. Genomic Analyses from Non-invasive Prenatal Testing Reveal Genetic Associations, Patterns of Viral Infections, and Chinese Population History. Cell 175:347-359 e14.

4. Readhead B, Haure-Mirande JV, Funk CC, Richards MA, Shannon P, Haroutunian V, Sano M, Liang WS, Beckmann ND, Price ND, Reiman EM, Schadt EE, Ehrlich ME, Gandy S, Dudley JT. 2018. Multiscale Analysis of Independent Alzheimer's Cohorts Finds Disruption of Molecular, Genetic, and Clinical Networks by Human Herpesvirus. Neuron 99:64-82 e7.

5. Eimer WA, Vijaya Kumar DK, Navalpur Shanmugam NK, Rodriguez AS, Mitchell T, Washicosky KJ, Gyorgy B, Breakefield XO, Tanzi RE, Moir RD. 2018. Alzheimer's DiseaseAssociated beta-Amyloid Is Rapidly Seeded by Herpesviridae to Protect against Brain Infection. Neuron 99:56-63 e3.

6. Gerard HC, Dreses-Werringloer U, Wildt KS, Deka S, Oszust C, Balin BJ, Frey WH, 2nd, Bordayo EZ, Whittum-Hudson JA, Hudson AP. 2006. Chlamydophila (Chlamydia) pneumoniae in the Alzheimer's brain. FEMS Immunol Med Microbiol 48:355-66.

7. Maheshwari P, Eslick GD. 2015. Bacterial infection and Alzheimer's disease: a meta-analysis. J Alzheimers Dis 43:957-66.

8. Parady B. 2018. Innate Immune and Fungal Model of Alzheimer's Disease. J Alzheimers Dis Rep 2:139-152.

9. Hategan A, Bianchet MA, Steiner J, Karnaukhova E, Masliah E, Fields A, Lee MH, Dickens AM, Haughey N, Dimitriadis EK, Nath A. 2017. HIV Tat protein and amyloid-beta peptide form multifibrillar structures that cause neurotoxicity. Nat Struct Mol Biol 24:379-386.

10. Lee NJ, Ha SK, Sati P, Absinta M, Luciano NJ, Lefeuvre JA, Schindler MK, Leibovitch EC, Ryu JK, Petersen MA, Silva AC, Jacobson S, Akassoglou K, Reich DS. 2018. Spatiotemporal distribution of fibrinogen in marmoset and human inflammatory demyelination. Brain 141:1637-1649.

11. Nath A. 2018. Association of Herpes Viral Infections, Antiherpetic Therapy, and Dementia: Real or Alternative Fact? Neurotherapeutics $15: 415-416$ 